of the Faculty of Agriculture and Horticulture, and continued to hold these positions in the College, and later in the University, until he retired in 1947. In 1948 he was awarded the C.B.E.

In the early days, Neville worked with Pope and Pickard on problems chiefly concerned with the optical activity of a variety of organic compounds. However, his Cambridge days show a complete change of subject, and his researches there dealt with such matters as the fat of yeast and the mucilage of linseed; he was also joint author of a paper on the relative value of white and wholemeal bread. Neville was always described as an excellent analyst and research worker by those who knew him, and in some ways it is to be regretted that the turn of events at Reading led him into administration. Nevertheless, he was the guiding spirit behind the many excellent soil surveys which were carried out by members of his staff between 1925 and 1940 .

What was lost to research was gained by the University and the Faculty, for Neville was a firstclass administrator. He was one of a small body of men who guided the University College in those important years immediately before the granting of the charter in 1926, and he was the real architect of its Faculty of Agriculture and Horticulture.

The committees connected with university work and particularly with agricultural education on which Neville served are too numerous to mention here; but it was through these that he became known to, and respected by, a large number of people.

H. A. D. Neville was a wise administrator, an excellent teacher and a very good conversationalist; he is gone, but the Faculty of Agriculture and Horticulture of the University of Reading will ever be his monument.

CyRIL TyleR

\section{Dr. F. B. Pidduck}

Frederick Bernard Pidduck, whose body was found on July 1 on a Lakeland mountainside, had lived at Keswick after his retirement in 1950 from a long and distinguished career in scientific research and teaching at Oxford. Born on July 17, 1885, at Southport, he proceeded from Manchester Grammar School to Exeter College, Oxford, where he gained first-class honours both in mathematics and physics, and also the junior and senior mathematical University scholarships. He then studied for a short time at the Technische Hochschule, Charlottenburg. From 1907 he was a Research Fellow of the Queen's College, Oxford, whence in 1921 he became Fellow and Tutor of Corpus Christi College, where the rest of his official life was spent. During 1916-18 he rendered war service as a research officer in ballistics, with rank of captain, at Woolwich Arsenal, where his work gained official commendation. In 1923 he was awarded the D.Sc.(Oxford) for a thesis that included two important contributions to the kinetic theory of gases. In 1927 he became University reader, having previously been lecturer, in applied mathematics; this position he resigned in 1934. Electrical theory was one of his main interests, and he published two textbooks on it, in 1916 and 1937, a technical treatise on currents in aerials and high-frequency networks (1946), and, with R. K. Sas, in 1947, an account of the M.K.S. system of electrical units, for which he was an enthusiast.

$\mathrm{He}$ was an extremely able mathematician, who preserved his intellectual originality and vigour to the end of his life. He wrote a series of important papers on the magnetron oscillator, and one of his last papers completes a theory of diffraction which he believed would ultimately take a fundamental place in optics. He was also a skilled experimenter, and long acted as senior demonstrator at the Electrical Laboratory, Oxford.

Active and athletic, Pidduck was an all-the-yearround swimmer, and an amateur photographer. $\mathrm{He}_{e}$ entered little into the life of his Colleges and University, and was apt to dwell on grievances. His reclusive habit unfortunately deprived his fellow workers of valuable contact with his able and wide-ranging mind, and may have contributed to what with some justification he felt to be an undue lack of public recognition of his notable achievements. One of his characteristics that he took trouble to conceal was his private generosity.

S. C.

\section{Colonel W. C. Devereux}

By the death on June 21 of Colonel W. C. Devereux, science has suffered a loss which is more serious than would normally be the case in the passing of an important and colourful industrial figure. For 'Dev', as he was universally called by his friends and these included his work-people-combined success in industry with a real appreciation of the value of scientific and industrial research.

This was based not so much on philanthropy as on a knowledge that scientific research was commercially sound and indeed an essential basis for the new and expanding industry of light metals. After the First World War, during which he was superintendent of the first national aircraft factory, he developed the technique of forging light alloy pistons and was in frequent contact with Dr. W. Rosenhain and his team at the National Physical Laboratory in their work on $Y$ alloy. The success of the forged piston in practice led to the formation in 1927 of High Duty Alloys, where the research laboratories, which were constantly expanding, were always an essential and integral part of the organization. Constantly in touch with the foundry and factory, the research laboratories none the less produced results of fundamental importance, as instanced by the work of Dr. L. Frommer on stress analysis by X-ray methods and on spectrographic analysis, and the studies of Dr. R. F. Hanstock and his collaborators on damping capacity.

On resigning from the office of chairman and managing director of High Duty Alloys in 1945, Colonel Devereux formed Almin, Ltd., and took the opportunity of founding the Fulmer Research Institute at Stoke Poges. His contacts with research and development in the United States during the Second World War had convinced him of the need in Great Britain for an organization for carrying out sponsored research to supplement the work of privato industrial laboratories and co-operative research associations. The growth of that organization, which has more than doubled its staff (which now includes more than thirty graduates) and trebled its income, is an indication of the soundness of his judgment. Although confident of the continued success of the Institute, we cannot over-estimate the loss we have suffered in the dynamic and zestful personality of our late chairman, who quickly became a personal friend to those of us who had the privilege of working for him. $\mathrm{E}$. A. G. Liddiard 